\title{
THE EFFECT OF SCIENCE INQUIRY LEARNING MODEL WITH PICTORIAL RIDDLE METHOD ON STUDENTS SCIENCE PROCESS SKILLS IN ELASTICITY TOPIC SENIOR HIGH SCHOOL PERCUT SEI TUAN CLASS XI ACADEMIC YEAR 2018/2019
}

\author{
Yuni Evany Sinaga ${ }^{1^{*}}$, Nurdin Siregar ${ }^{1}$, and Disna Margaretha ${ }^{2}$ \\ ${ }^{1}$ Department of Physics Faculty of Mathematics and Natural Sciences, Medan State University \\ ${ }^{2}$ Science Department Faculty of Mathematics and Natural Sciences, Medan State University \\ St. Williem Iskandar Psr. V Medan Estate, Medan, Indonesia, 20221 \\ *yuni.evany@gmail.com
}

Accepted: November $11^{\text {th }}, 2019$. Published: November $26^{\text {th }}, 2019$

\begin{abstract}
This study aimed to determine the effect of scientific inquiry learning with pictorial riddle method on students' science process skills in the subject elasticity in senior high school Percut Sei Tuan. This research was a quasi-experiment with two group pre-test post-test design. The population in this study were all students of class XI MIA SMA N 2 Percut Sei Tuan consisting of 4 classes totalling 140 students. The study sample consisted of two classes, namely the XI MIA-1 class as the experimental class and the XI MIA-2 class as the control class with 35 and 34 students, respectively. The instrument used was an essay test of science process skills. Based on the data analysis, it was found that there was a significant effect of the scientific inquiry learning with the pictorial piddle method on students' science process skills in the subject elasticity in Senior High School 2 Percut Sei Tuan.
\end{abstract}

Keywords: science process skills, scientific inquiry, elasticity 


\section{Introduction}

Education is a conscious effort carried out by adults (educators), in carrying out selfdevelopment activities of students to become complete human beings under predetermined goals. Education is guidance or leadership consciously by educators on the physical and spiritual development of students, towards the formation of the main personality according to certain sizes (Kompri, 2016)

Educational objectives (Ministry of National Education, 2003) in Law Number 20 of 2003 concerning Article 3 of the National Education System, "The aim of national education is to develop the potential of students to be faithful and devoted to God Almighty, noble, healthy, knowledgeable, capable, creative, independent, and a democratic and responsible citizen." Indonesia is still very far from national education goals. The big problem faced by the Indonesian people is the low quality of education. One indicator that can show the low quality of education in Indonesia is through the 2015 Program for International Student Assessment, which shows Indonesia is ranked 69th out of 76 countries surveyed for the natural sciences field (Hayat and Suhendra, 2010).

Physics is one of the lessons that drains a lot of energy to think, and is one of the most influential lessons in today's technological development. This great influence makes physics lessons very important to learn. Physics lessons should be taught with skills training that contains activities that enable students to develop the ability to solve problems, such as formulating problems, testing hypotheses, collecting and processing data and drawing conclusions. The fundamental aspect possessed by physics is its existence as knowledge born from observations and facts, meaning that in understanding something about natural phenomena, physics always bases observational or observational activities and obtains their truth empirically through the five senses. These observations and facts form the physical concepts that underlie the formation of physics. Physics concepts transferred from teacher to student should also be emphasized direct observation activities. This is intended to form a clear and correct concept as a whole.

Researchers have made initial observations by giving questionnaires to students of Senior High School 2 Percut Sei Tuan in class $\mathrm{XI}$ as many as 35 people. The results of the questionnaire found that students who like physics and are active in physics learning in the class were only $20 \%$. Then the second, $65 \%$ don't really like physics, and the third $15 \%$ don't like physics. The teacher still uses the teacher-oriented learning process, where students are less active in learning. The results of interviews from the subject teachers concerned, he confirmed that the low student learning outcomes in physics because students feel quickly saturated with physics. The problem in the learning process is that students are not encouraged to develop thinking skills. Classroom learning is directed at students' ability to memorise information; children's brains are forced to remember and hoard a variety of information without understanding information related to everyday life.

Data from observations that researchers have done to find out the opinions of students about physics lessons, explained that students are less motivated to learn in physics and think that physics is a difficult and boring lesson caused by many factors, the first is a lack of variations in learning models and learning media that are used by teachers when carrying out learning activities. Students also rarely use practicum when learning physics. This raises the desire of students to learn to be very far from expectations and will have an impact on learning outcomes obtained by students. The low learning outcomes and science process skills of students because learning activities are not optimal in facilitating students. Science process skills students need a learning model that trains students to be skilled in conducting scientific investigations in discovering concepts and principles as well as the laws of physics. It is evident from the interview of one of the teachers that there are still student learning outcomes in the school that have not yet reached the Minimum Completion Criteria (KKM), which is 75 .

The fact above shows that there needs to be a change in the teaching-learning system that occurs one way to change the teaching and learning system in class so effective is to apply the appropriate learning model. Researchers offer models that can overcome the above problems and improve students' science process skills, namely the scientific inquiry learning model. Scientific inquiry is an activity that identifies problems, conducts scientific experiments to collect data, applies numerical and statistical methods to reach and support conclusions, formulate hypotheses and use available technology (Joyce et al, 2009). This learning model emphasizes the development of cognitive, affective, and psychomotor aspects in a balanced manner so that learning through this model is 
considered more meaningful. This learning model also provides space for students to learn according to their learning. Besides this learning model is a model that is considered in accordance with the development of modern learning psychology which considers learning is a process of changing behaviour thanks to experience. Schwab (Joyce et al., 2009) suggested that the Scientific Inquiry designed to teach the research system of discipline, but also expected to have effects in other domains; sociological methods may be taught in order to increase social understanding and social problem solving (Scientific Inquiry learning models are designed for learning research systems of discipline, and also have effects in other domains; social methods can be taught to improve social understanding and social problem solving). In the Scientific Inquiry learning model, students are guided by the teacher in understanding the concept through a series of experiments.

Riddle pictorial method is a method or technique for developing student activities in small and large group discussions, through the presentation of problems presented in illustrative form. The reason researchers in learning physics uses pictorial riddle because physics is inseparable from images, physics materials, especially elasticity and Hooke law require images to clarify students' understanding so that when teachers give lessons students can immediately capture material delivered by the teacher. Without pictures, students have difficulty accepting lessons or just wishful thinking. The application of this learning is expected that students can be more active in participating in the learning process of teaching physics and can obtain maximum learning outcomes, so as to increase understanding of the concept of a material (Kristianingsih et al, 2010).

Clara (2014) conducted a study, namely, analyzing the scientific inquiry learning model and scientific attitude towards students' science process skills in physics. The study showed that the science process skills of students taught using scientific inquiry learning models were better than direct learning models, science process skills of students who had high scientific attitudes were better than students who had a low scientific attitude and there were interactions between learning models scientific inquiry and scientific attitude towards students' physical science process skills where this learning model is better applied to students who have high scientific attitudes.
Puji and Abdullah (2015) with scientific inquiry learning analysis and the ability to think creatively on the learning outcomes of high school students and the results of the study showed that the scientific inquiry learning model is better than conventional learning in improving student learning outcomes, learning outcomes in groups of students who have the ability high creative thinking is better than the group of students with low creative thinking skills, and there is an interaction between the scientific inquiry learning model and the ability to think creatively in influencing student learning outcomes. The difference between this research and the previous research is that researchers did not only use the scientific inquiry learning model, the media in learning. This is expected to improve student learning outcomes.

The background of the above problems underlies the authors researching with the aim of knowing The Effect of Scientific Inquiry Learning Model with Pictorial Riddle Method on Science Process Skills Student in Class XI, Elasticity Topic in Semester I Senior High School 2 Percut Sei Tuan Academic Year 2018/2019.

\section{Research Method}

The research was conducted at Senior High School 2, Percut Sei Tuan, academic year 2018/2019. The population in the study were all students of class XI MIA Semester I of Senior High School 2 Percut Sei Tuan Academic year 2018/2019 totalling 140 people, consisting of 4 classes. The study sample consisted of two classes namely class as a control class using conventional learning models.

This type of research was quasiexperimental or quasi-experimental with the design of two group pre-test post-test designs can be seen in Table 1.

Table 1. Two Group Pre-test Post-test Design

\begin{tabular}{|l|c|c|c|}
\hline Kelas & Pretes & treatment & Postes \\
\hline Experiment & $\mathrm{T}_{1}$ & $\mathrm{X}$ & $\mathrm{T}_{2}$ \\
\hline Control & $\mathrm{T}_{1}$ & $\mathrm{Y}$ & $\mathrm{T}_{2}$ \\
\hline
\end{tabular}

Keterangan :

$\mathrm{T}_{1} \quad$ : Initial Test (pre-test)

$\mathrm{T}_{2} \quad$ : Final Test (post-test)

$\mathrm{X}$ : applying scientific inquiry learning model with the pictorial riddle method

Y : the application of conventional learning

The researcher gave a pre-test in the experimental class and the control class. The 
instrument used in this study is a test of students' science process skills practicum in the form of a practicum and also an instrument for the assessment of science process skills activities in the experimental class because it is needed to see how PPP activities occur when using learning models. The pre-test data of students' science process skills were analyzed by testing the hypothesis of two parties to determine the initial ability of KPS students in both classes with the condition that normality and homogeneity tests should be carried out.

The researcher then conducts learning by using the scientific inquiry learning model with the pictorial riddle method in the experimental class and the conventional learning model in the control class. The researcher gave a post-test after being given different treatments in both classes. Post-test data were analyzed by carrying out the normality test, homogeneity test, and oneparty hypothesis test to find out the difference in the final results whether there was influence of the scientific inquiry learning model with the pictorial riddle method on students' science process skills.

\section{Results and Discussion}

\section{a. Research Result}

There are two kinds of research data, namely tests and observations of science process skills. The results of the pre-test of the experimental class students and the control class are shown in Figure 1.

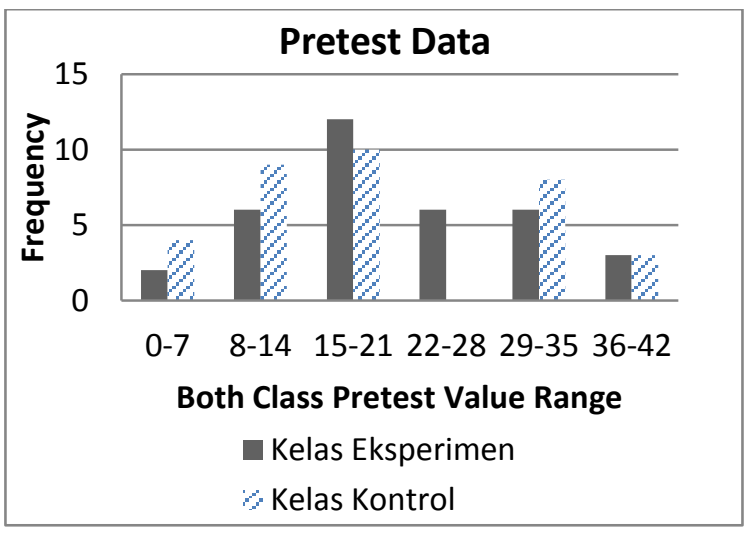

Figure 1. The results of Both Class Pretest

Figure 1 shows that the highest frequency of the pre-test results of students in both classes is in the range of 15-21. Based on existing data, it was obtained $t_{\text {count }}=0,854$ and $t_{\text {tabel }}=1,998$ so with $t_{\text {cou }}<t_{\text {tabel }}(0,854<$ 1,998) then both classes have the same initial ability (there is no significant difference to KPS).
The post-test results of the experimental class and control class students are shown in Figure 2 and Figure 3.

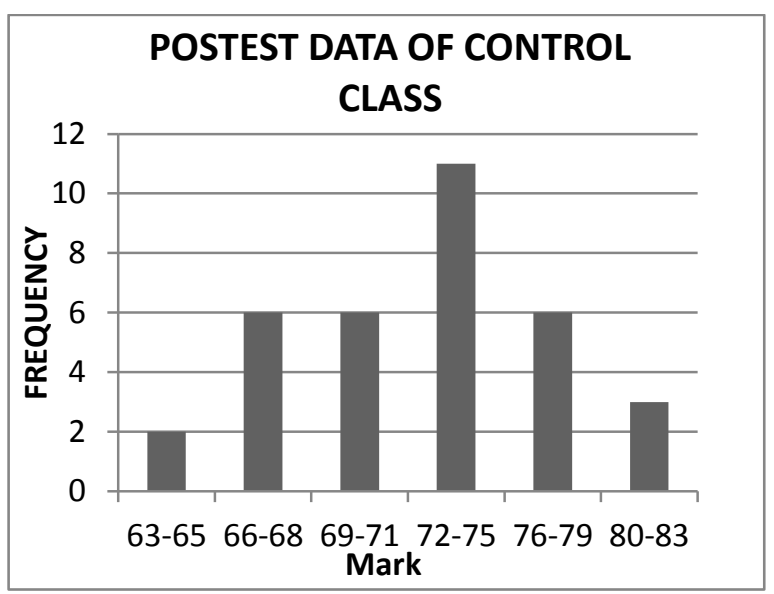

Figure 2. The results of experiment class Posttest

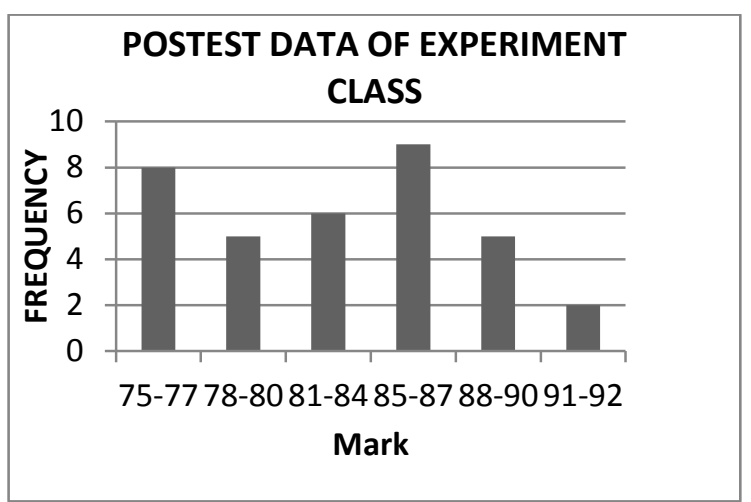

Figure 3. Hasil Postes Kelas Kontrol

Figures 2 and 3 show that differences in the results of the experimental class post-test and control class, were based on the data obtained $\mathrm{t} \_$count $=5.910$ and $\mathrm{t} \_$table $=1.670$ with the test criteria t_count > t_table (5.910>1.670). From the difference in values, it can be concluded that the inquiry scientific model with the Riddle pictorial method has an influence on the students' Science Process Skills in the material of Elasticity in class XI of SMA 2 Percut sei Tuan in the first semester, Academic Year 2018/2019.

Improving the science process skills of students in the experimental class can be seen through the results of student KPS observations which include the process of observing, collecting and processing data, identifying and controlling variables, formulating and testing hypotheses, formulating explanations, and concluding shown in Table 2 . 


\begin{tabular}{|l|c|c|c|}
\hline \multirow{2}{*}{ KPS Aspects } & \multicolumn{3}{c|}{ Marks } \\
\cline { 2 - 4 } & I & II & III \\
\hline Observe & 36 & 58 & 75 \\
\hline $\begin{array}{l}\text { Collecting and processing } \\
\text { data }\end{array}$ & 58 & 61 & 80 \\
\hline $\begin{array}{l}\text { Identifying and controlling } \\
\text { variables }\end{array}$ & 50 & 63 & 81 \\
\hline $\begin{array}{l}\text { Formulating and Testing } \\
\text { Hypotheses }\end{array}$ & 59 & 54 & 79 \\
\hline Formulate an explanation & 54 & 68 & 80 \\
\hline Concluding & 65 & 74 & 80 \\
\hline
\end{tabular}

Table 2. Student Science Process Skills Observation Results

\section{b. Discussion}

The results of the study were able to show that there was a significant effect on students' science process skills by using the inquiry scientific learning model with the pictorial riddle method on the material of elasticity in the first semester of class XI in Senior High School 2 Percut Sei Tuan Academic year 2018/2019. This is reinforced by the increase in the average value of science process skills of experimental class students is higher than the control class, namely the average value of pretest 21.37 and posttest average value of 82.69 in the experimental class while in the control class the average value is obtained -the pretest is 19.21 and the post-test average value is 73.71. A significant increase in the experimental class occurred because the stages in the inquiry scientific model with the pictorial riddle method were well implemented.

The success of the inquiry scientific learning model with the pictorial riddle method is because the scientific learning model of inquiry is able to make students observe, collect and process data, identify and control variables, formulate and test hypotheses, formulate explanations, and conclude, according to indicators of science process skills. The research that supports this is Puji \& Abdullah (2015) with the results of his research showing that the scientific inquiry learning model is better than conventional learning in improving students' science process skills and having high creative thinking skills. This scientific inquiry learning model is also able to motivate students to learn by providing opportunities for them to build their own meanings and develop deep understanding. The inquiry scientific learning model with the pictorial riddle method helps students improve students' fighting ability in solving a problem. Students are also interested and active when discussing and issuing different opinions when discussions between groups are held. Then in the scientific inquiry learning model students are able to develop their science process skills in each of the stages of learning.

The above can be described in the teaching and learning process in the XI MIA-1 class as an experimental class which is where students carry out inquiry processes to find the concepts given to the elasticity material at each scientific inquiry stage. Learning with the scientific learning model of inquiry is more effective in developing students' science process skills because the indicators of science process skills are very relevant and integrated into the scientific inquiry learning phases. Indicators of science process skills which consist of measuring, collecting and processing data, identifying and controlling variables, formulating and testing hypotheses, and formulating explanations, and drawing conclusions can all develop in scientific inquiry learning.

The first phase of scientific inquiry learning is that students are presented with a field of research by the way the teacher tells student representatives to demonstrate and then directs all students to observe the existing problems. Observing is very necessary for learning.

The second phase, students arrange problems by collecting information about the events they see/observe which can also train students' ability to observe or observe an event, classify/classify the information they have obtained, and measure objects correctly. The information obtained is used as a basis for formulating hypotheses so that students can improve their scientific skills in formulating hypotheses.

The third phase, students identify problems in the study, meaning students are given the opportunity to speculate about problems by conducting experiments, where they answer the problems given by the teacher through the experiment so that in this phase students will be trained to design experiments, using the tools/materials and sources they get from the previous phase and identify variables that involve students' science process skills. In experiments students experience and take measurements, record measurement results, and process experimental data. All of these activities support the development of students' science process 
skills. In addition, students discover and build their own knowledge.

The fourth phase, students speculate to speculate about ways to explain the difficulties and formulate an explanation that they can both from experiments and from the results of students' experiences and thoughts. Participation in experimental activities trains students to explain. Then students connect the results of observations and find patterns or regularities from the results of observations found to draw conclusions. All of these activities support the development of science process skills, namely concluding.

These stages students are formed in groups and are given the opportunity to experiment to find answers to the material provided, and the answers are expressed in the student worksheet. In conducting experiments students in groups make observations and record their findings. At the time of conducting experiments, students' science process skills began to develop. This is what affects the value of the final test or post-test of students. This has also been proven by Hussain et al (2011) which states that there are significant differences between the methods of conventional scientific inquiry and learning on student learning outcomes.

The teaching and learning process in class XI MIA-2 as a control class researchers delivered material with lectures and gave individual assignments to students, students only listened and some students recorded what was delivered. Almost no students ask questions or answer questions given during learning. Conventional learning models carried out in the control class according to students tend to be boring because only one lecture listens without doing so students are less active in learning. The lack of scientific activities during learning leads to low student science process skills. The researcher also carried out observations of the science process skills of students in the experimental class conducted by observers at each meeting. Where in this study four observations were carried out. The results of the observations indicate an increase in the value of activities of students' science process skills in each aspect contained in the syntax of inquiry.

This research is supported by previous research as researched by Safarati (2017), where the results of the research average value of science process skills of the experimental class students 86.5 and the control class 80.5. Clara (2014) obtained conclusions From the results of the study it can be concluded that: 1) student learning outcomes taught using the scientific inquiry learning model are better than the direct learning model; 2) learning outcomes of students who have a high scientific attitude better than students who have a low scientific attitude.

During learning there are obstacles for researchers, among others: 1) Unconditioning the classroom atmosphere. This is caused by students who are active in carrying out lab work so that it makes the atmosphere less conducive. Overcoming this, the teacher should guide the class so that it is more conducive to the classroom atmosphere. 2) Ignorance of the use and workings of a good tool, this is caused by students not reading the procedure properly, therefore teachers should better facilitate the language in student worksheets and give examples when practicum 3) lack of readiness of the researcher, 4) students who do not accustomed to conducting experiments causes the amount of time wasted explaining work steps and guiding students. This can be overcome by the teacher's habits in the classroom teaching students to use lab work.

\section{Conclusion and Suggestion}

\section{a. Conclusion}

Based on the results of the research and analysis of the data obtained, it can be concluded that there is the influence of the inquiry scientific learning model with the pictorial riddle method on the science process skills of students in the material of elasticity in class XI of Senior High School 2 Percut Sei Tuan Academic Year 2018/2019.

\section{b. Suggestion}

The suggestions obtained by researchers from the research conducted are that the next researcher should be able to use the available time and try to maintain class conduciveness and provide sufficient tools and materials so that all stages in the inquiry learning scientific model with the pictorial method can be carried out properly and maximally.

\section{References}

Clara, (2014), Analisis Model Pembelajaran Scientific Inquiry Dan Sikap Ilmiah Terhadap Hasil Belajar Siswa Pada Pelajaran Fisika, Jurnal Pendidikan Fisika, 3 (2), 22-25. 
Hayat, B. \& Suhendra, (2010), Benchmark Internasional Mutu Pendidikan, Jakarta : Bumi Aksara.

Hussain, A., Azeem, M., \& Shakoor, A., (2011), Physics Teaching Methods: Scientific Inquiry $\mathrm{Vs}$ Traditional Lecture, International Journal of Humanities and Social Science, 1(19), 269-276.

Joyce, B., Weil, M., \& Calhoun, E., (2009), Model-Model Pengajaran Edisi Delapan, Yogyakarta : Pustaka Belajar.

Kompri, (2016), Manajemen Pendidikan Komponen-Komponen Elementer Kemajuan Sekolah, Yogyakarta : ARRUZZ MEDIA.

Kristianingsih, Sukiswo, S. \& Khanafiyah, S., (2010) Peningkatan Hasil Belajar Siswa melalui Model Pembelajaran Inkuiri dengan Metode Pictorial Riddle pada Pokok Bahasan Alat-alat Optik di SMP, Jurnal Pendidikan Fisika, 2 (6): 15-21.

Puji, D. \& Abdullah, R., (2015), Analisis Model Pembelajaran Scientific Inquiry Dan Kemampuan Berpikir Kreatif Terhadap Keterampilan Proses Sains Siswa SMA, Jurnal Pendidikan Fisika, 4 (2), 47-54.

Safarati, N., (2017), Pengaruh Model Scientific Inquiry Menggunakan Media Phet Terhadap Keterampilan Proses Sains Ditinjau Dari Keterampilan Berpikir Kritis, Jurnal Pendidikan Fisika, 6 (1), 33-38. 